\title{
HEDGE FUND DUE DILIGENCE: A SOURCE OF ALPHA
}

\section{IN A HEDGE FUND PORTFOLIO STRATEGY}

\author{
Stephen J. Brown, Thomas L. Fraser, Bing Liang ${ }^{1}$ \\ First Draft: July 18, 2007 \\ Current draft January 21, 2008
}

\begin{abstract}
$\underline{\text { Abstract }}$
Due diligence is an important source of alpha in a well designed hedge fund portfolio strategy. It is generally understood that the high returns possible in investing in hedge funds are somewhat offset by the relative lack of transparency on operational issues. The performance of a diversified hedge fund portfolio can be enhanced by excluding those funds likely to do poorly - or fail - due to operational risk concerns. However, effective due diligence is an expensive concern. This implies that there is a strong competitive advantage to those funds of funds sufficiently large to absorb this fixed and necessary cost. The consequent economies of scale that we document in funds of funds are quite substantial and support the proposition that due diligence is a source of alpha in hedge fund investment.

JEL Classification: G1, G2
\end{abstract}

Keywords: Hedge funds, operational risk, due diligence, alpha

Contact author

Stephen J. Brown

David S. Loeb Professor of Finance

NYU Stern School of Business

44 West $4^{\text {th }}$ Street, Suite 9-190

New York, NY 10310

Telephone: 2129980306

FAX: $\quad 7189817239$

e-mail: $\quad$ sbrown@stern.nyu.edu

\footnotetext{
${ }^{1}$ Stephen J. Brown is the David S. Loeb Professor of Finance at New York University Stern School of Business, Thomas L. Fraser is an attorney in New York City and Bing Liang is Associate Professor of Finance at the University of Massachusetts at Amherst - Department of Finance \& Operations Management. Please direct email correspondence to sbrown@stern.nyu.edu and tom@tlfraser.com.
} 


\section{Introduction}

Funds of hedge funds ("funds of funds") are a popular way for investors to invest in hedge funds. Funds of funds provide investors with diversification by investing in multiple hedge fund managers representing multiple investment styles. Funds of funds also provide investors with asset allocation and manager due diligence, selection and monitoring. Funds of funds generally require lower initial investments than hedge funds. Some funds of funds provide investors with access to managers otherwise closed to new investment. For their services, fund of funds managers charge investors with an extra layer of fees. Consequently, returns for funds of funds are generally lower than for hedge funds $^{2}$. As of June 30, 2006, the 50 largest fund of funds managers managed approximately $\$ 550$ billion in assets. ${ }^{3}$

Hedge funds on average generate positive alpha. While investing in hedge funds can result in high returns, it is generally understood that the high returns are somewhat offset by a relative lack of transparency on operational issues. Feffer (2003) argues that operational risk as distinct from financial risk accounts for a substantial fraction of fund attrition. While in extreme cases operational risk events can lead to fund failure, Brown et al. (2007) show that operational risk associated with conflicts of interest both within the fund and external to the fund can lead to a reduction in return of on average of 1.68 per cent on an annualized basis. Given that operational risk is a major cause of hedge fund attrition and underperformance, it follows that the performance of a diversified hedge fund portfolio can be enhanced by excluding those funds likely to do poorly - or fail -

\footnotetext{
${ }^{2}$ See Brown et al. (2004).

${ }^{3}$ Martin, Scott, “Growing Places,” Institutional Investor (November 2006), Vol. 40, Issue 11, p. 103.
} 
due to operational risk concerns. However, effective due diligence is expensive ${ }^{4}$. Thus, funds of funds large enough to absorb the high cost of due diligence have a significant competitive advantage over smaller funds of funds. The economies of scale we document in funds of funds are quite substantial and support the proposition that due diligence is an important source of alpha in hedge fund investment.

The rest of this paper is organized as follows. Section II describes the due diligence process and distinguishes two types of due diligence: operational due diligence and financial due diligence. Section III reviews literature on hedge fund returns, hedge fund attrition and operational risk and describes how due diligence can provide a competitive advantage. Section IV describes data from TASS and presents an analysis of hedge fund and fund of funds returns. Finally, Section V concludes with a summary of our major findings.

\section{Due Diligence}

\section{A. “Due Diligence” Defined}

Hedge fund due diligence is the process of reviewing and monitoring the operation and management of hedge fund managers. The objectives of due diligence are to identify managers with whom to invest and to monitor those managers on an ongoing basis in order to ensure that investing with them is appropriate for the interests of the investor. Due diligence consists of a thorough qualitative and quantitative examination of the hedge fund manager, personnel, investment strategies, business structure, operations,

\footnotetext{
${ }^{4}$ Ang et al. (2005) argue that it is the cost of providing this due diligence function that justifies the fees that funds of funds charge over and above the fees charged by constituent funds.
} 
alignment of interests, conflicts of interest, valuation policies and procedures, risk

management, compliance, investment terms, criminal, civil and regulatory actions, and competitive advantage, among other things ${ }^{5}$. Properly done, due diligence provides a thorough analysis and understanding of the potential operational and financial risks involved with investing with a specific manager.

\section{B. Operational Due Diligence and Financial Due Diligence Distinguished}

The International Association of Financial Engineers defines operational risk as "losses caused by problems with people, processes, technology, or external events.”6 Operational risk is very broadly defined and includes risks associated with accounting, operations, compliance, audit, valuation, reporting and the oversight of personnel. Brown et. al (2007) find that as potential conflicts of interest between managers and investors increase, operational risk increases as well. Legal and regulatory problems are also indicators of operational risk. Operational risk is distinguished from financial risk, which includes poor investment performance and excessive investment risk. The purpose of operational due diligence is to review and monitor funds with respect to operational risk.

\footnotetext{
${ }^{5}$ The actual due diligence practices of funds of funds vary widely. Some funds of funds devote 100 or more hours of due diligence annually to each fund in which they invest and make multiple on-site visits before making their initial investment. Other funds of funds rely primarily on due diligence reports prepared by consulting firms. Some funds of funds perform little formal due diligence other than to review fund performance figures and offering documents. Industry best practices for due diligence include: reviewing valuation practices and procedures, especially with respect to complex and illiquid investments; reviewing internal control policies and procedures, such as whether one or two signatures are required to move money out of the fund; performing background checks and interviewing industry peers of fund senior management; reviewing conflicts of interest; and interviewing auditors, administrators, prime brokers, attorneys and other outside service providers.

${ }^{6}$ International Association of Financial Engineers, Report of the Operational Risk Committee: Evaluating Operational Risk Controls, Conclusions and Findings on the Topic of: "How should firms determine the effectiveness of their operational risk controls?” (November 2001). Available at: www.iafe.org/documents/EvaluatingOperationalRiskControls-WhitePaper.pdf.
} 
The purpose of financial due diligence is to review and monitor funds with respect to financial risk.

The implosion of Amaranth illustrates the distinction between financial risk and operational risk. Amaranth was widely reported in the financial press as having failed due to an energy trading strategy that went awry (financial risk). However, operational issues may well have contributed significantly to its demise. A due diligence report completed more than a year prior to its failure led at least one investor to pull their money out of the fund at a significant financial penalty. This report identified significant operational risk factors at Amaranth, including "the lack of an independent third-party administrator verifying returns, insufficient risk controls and the passing through of company expenses to the fund."

Operational risk and financial risk are often closely linked. Unlike financial risk, operational risk is not easily diversifiable. An investor must do operational due diligence on every fund in which it invests. Additionally, a fiduciary delegating investment and management functions is required to perform appropriate due diligence ${ }^{8}$.

\footnotetext{
${ }^{7}$ Hosking, Patrick, “Investor paid out extra penalties to quit Amaranth,” The Times (of London), October 13, 2006, p. 50. The article also notes that "High leverage, poor transparency and a hubristic management team were other unnerving signals, as well as Amaranth's well-known reliance on a single trading strategy - energy trading.” http://business.timesonline.co.uk/tol/business/markets/united states/article599997.ece. While reliance on a single energy trading strategy at Amaranth led to a financial risk event, this reliance suggests problems in operations and control given that the fund characterized itself on its website as a multi-strategy fund deploying capital in a broad spectrum of alternative investment strategies in a highly disciplined risk-controlled manner.

${ }^{8}$ Under the Uniform Prudent Investor Act, a fiduciary is required to invest in a prudent manner. The UPIA permits a fiduciary to delegate investment and management functions. If a fiduciary delegates an investment function, the fiduciary is required to exercise "reasonable care, skill, and caution" in selecting a manager and monitoring the manager's performance. (Uniform Prudent Investor Act (1994)). In other words, a fiduciary that delegates investment functions is required to perform prudent monitoring and due diligence on an ongoing basis.
} 


\section{Hedge Fund Returns, Hedge Fund Attrition and Operational Risk}

\section{A. Hedge Funds Generate Alpha}

Hedge funds on average generate positive alpha. Brown, Goetzmann and Ibbotson (1999) find that offshore funds as a group have positive risk-adjusted performance when measured by Sharpe ratios and by Jensen's alpha. Kouwenberg (2003) finds that a majority of hedge funds have positive alphas on an after fee basis. Ibbotson and Chen (2006) also find that hedge fund alphas are significantly positive even after accounting for well known survivorship and backfill biases. Many other researchers have also studied hedge fund returns and found positive and significant alphas, including Liang (2000), Edwards and Caglayan (2001), Asness, Krail and Kiew (2001) and Fung and Hsieh (2004).

\section{B. Lack of Operational Transparency}

While investing in hedge funds can result in high returns, it is generally understood that the high returns are somewhat offset by the relative lack of transparency on operational issues. There are a variety of reasons why hedge funds have a relative lack of transparency on operational issues. Unlike registered investment companies (mutual funds), hedge funds are generally not subject to the long list of statutory disclosure requirements of the Investment Company Act of 1940. Unless a hedge fund manager is a registered investment adviser in the United States (or the equivalent in another jurisdiction), hedge fund managers are not required to make lengthy disclosure about operational matters. Hedge fund managers are also highly concerned about 
compromising their investment, business and organizational strategies and processes.

Thus, although hedge funds oftentimes pursue investment strategies with high degrees of complexity, illiquidity and operational risk, managers are generally reluctant to be transparent about operational issues.

A lack of operational transparency poses a variety of risks for investors and potential investors. Without sufficient operational transparency, it is much more difficult, expensive and time-consuming for investors to perform adequate due diligence with respect to operational risk ${ }^{9}$. As we discuss in Section III.C. of this paper, operational risk is a significant cause of hedge fund attrition and underperformance. Given that operational risk can have a significant negative impact on hedge fund performance, operational risk deserves considerable attention in the due diligence process.

\section{Hedge Fund Failure and Underperformance}

Hedge funds go out of business at a highly predictable rate. While the number of hedge funds that "blow up" and capture the headlines is relatively small, the percentage of hedge funds that go out of business on an annual basis is not insignificant. Brown, Goetzmann and Ibbotson (1999) find that the attrition rate for hedge funds is about $15 \%$ per year and that the "half-life" for hedge funds is about 2.5 years. Using a different data set, Liang (2001) finds an attrition rate of 8.54\% per year for hedge funds. Amin and Kat (2003) find that the attrition rate has increased substantially over time, which they attribute to an exogenous change in hedge fund managers' attitudes and expectations.

\footnotetext{
${ }^{9}$ Brown et al. (2007) observe that the consequent operational risk was a major motivation for the ill-fated effort on the part of the Securities and Exchange Commission to require hedge funds to register as investment advisors and to file the required Form ADV.
} 
Amin and Kat observe that managers close down much quicker than they did half a decade earlier.

The causes of hedge fund attrition are diverse. They include poor performance, operational failure and business failure resulting from, among other things, undercapitalization and the failure to accumulate sufficient assets under management. Brown, Goetzmann and Park (2001) find that fund attrition is correlated to excess risk and poor relative performance. Amin and Kat (2003) find that lack of size and lack of performance are important factors behind hedge fund attrition and that the attrition rate is much higher among small hedge funds than among large hedge funds.

Operational failure is a significant cause of hedge fund liquidations. In a study of more than 100 hedge funds liquidations over 20 years, Feffer and Kundro (2003) find that " $54 \%$ of failed funds had identifiable operational issues and half of all fund failures could be attributed to operational risk alone." Of the funds in their study that were liquidated due to operational failures, $41 \%$ of liquidations involved misrepresentation of investments and performance, 30\% involved misappropriation of funds and general fraud, $14 \%$ involved unauthorized trading and style breaches, $6 \%$ involved inadequate resources and $9 \%$ involved other operational failures. In addition to the $54 \%$ of fund failures in their study that had operational issues, Feffer and Kundro find that 38\% of hedge fund liquidations could be attributed to investment risk only and the remaining $8 \%$ could be attributed to business risk or a combination of risks. 
In addition to being a major cause of hedge fund attrition, operational risk is also a cause of hedge fund underperformance. Brown et al. (2007) find that operational risk is negatively related to fund returns, particularly when there are conflicts of interest between managers and investors. In a similar context, Brown et al. also find that the more concentrated a fund's management, the lower the returns. Fund operational risk characteristics seem to be understood by those providing leverage to the funds. However, operational risk does not mediate the naïve tendency of investors to chase past returns despite the fact that as this study shows, operational risk has a material and quite negative impact on investor returns.

\section{Enhancing the Performance of a Diversified Hedge Fund Portfolio}

Given that operational risk is a major cause of hedge fund attrition and underperformance, it follows that the performance of a diversified hedge fund portfolio can be enhanced by excluding those funds likely to do poorly - or fail - due to operational risk concerns. Obviously, funds that underperform for operational risk reasons will lower the overall return of a diversified portfolio. Thus, excluding them through thorough operational due diligence will enhance the returns of the portfolio. Additionally, excluding funds likely to go out of business for operational risk reasons enhances the overall return of a diversified portfolio in several different ways. As discussed in Section III.C., fund attrition is correlated to excess risk and poor relative performance. Funds that go out of business are a drag on the risk-adjusted returns of a portfolio. Funds that go out of business are also a drag on the expenses of a fund of funds. Additional money and time must be spent on due diligence to identify a new 
hedge fund to replace the one that has gone out of business. Transition costs are involved with redeeming an investment in a closed fund and investing in a new fund. A period of time may also be involved when the fund of funds is not fully invested in its optimal portfolio.

\section{E. The High Cost of Due Diligence}

Effective hedge fund due diligence is expensive, in terms of money and time. Effective due diligence requires the expenditure of a significant amount of time. According to Anson (2006), a thorough investor should expect to spend 75 to 100 hours reviewing a hedge fund manager before investing. One investor, the Princeton University Investment Company, is even more thorough. Andrew Golden, President of the Princeton University Investment Company, said that his organization spends at least 400 hours on initial due diligence before investing in a hedge fund and then approximately 70 hours per year on ongoing due diligence. ${ }^{10}$

The cost of due diligence is highly variable, depending on a number of factors, including its length of time and degree of thoroughness and whether law firms, accounting firms, consulting firms or other third party service providers are used. Assuming a conservative cost of due diligence of $\$ 50,000$ to $\$ 100,000$ per hedge fund ${ }^{11}$, the cost of

\footnotetext{
${ }^{10}$ See "Testimony of Andrew K. Golden, President of the Princeton University Investment Company, presented to the Financial Services Committee, United States House of Representatives” (March 13, 2007). Available at: www.house.gov/apps/list/hearing/financialsvcs_dem/ht031307.shtml.

${ }^{11}$ In practice, the cost of due diligence varies widely among funds of funds. One of the main reasons costs vary widely is because staffing and due diligence practices vary widely as well. Some of the largest funds of funds have several professionals dedicated exclusively to operational due diligence and use consulting firms, law firms, accounting firms and other third party service providers as well. Some funds of funds rely almost exclusively on consultants. Other funds of funds rely on industry word of mouth and perform little formal due diligence. Consulting firms offer a wide variety of due diligence services. Background checks
} 
performing initial due diligence on 10 hedge funds ${ }^{12}$ for a fund of funds portfolio would be $\$ 500,000$ to $\$ 1$ Million. Obviously, the cost of performing due diligence on hedge funds in which a fund of funds does not invest would be additional. Funds of funds typically review a multiple of the hedge funds in which they invest, so the direct cost of performing due diligence would be much higher than $\$ 500,000$ to $\$ 1$ Million. The cost of ongoing due diligence and costs relating to due diligence, such as the cost of building a database of hedge fund information, would also be additional.

\section{F. Competitive Advantage}

Due diligence can enhance the performance of a diversified hedge fund portfolio. But effective due diligence is very expensive. Thus, funds of funds large enough to absorb the high cost of due diligence have a strong competitive advantage over smaller funds of funds. As discussed above, a very conservative estimate of the cost of initial due diligence for a fund of funds portfolio consisting of 10 hedge funds is well in excess of $\$ 500,000$ to $\$ 1$ Million. Small funds of funds are at a competitive disadvantage because, based on assets under management, they are not able to generate sufficient management fees to cover the fixed and necessary cost of initial due diligence, let alone all the other business, administrative and operational costs of operating a fund of funds.

on fund management are one area in particular where funds of funds use consulting firms. The $\$ 50,000$ to $\$ 100,000$ figure used in this paper represents an approximation of the cost of performing prudently thorough due diligence. By way of comparison, the cost of obtaining a hedge fund operations quality rating from one of the ratings agencies is approximately $\$ 50,000$ to $\$ 100,000$, depending on the complexity of the hedge fund organization.

${ }^{12}$ There is, of course, the debate about the optimum number of hedge funds for a fund of funds portfolio. Most funds of funds invest in between 15 and 40 hedge funds. On the other hand, Lhabitant and Learned (2002) found that 5-10 hedge funds would provide most of the benefits of diversification. Obviously, if a fund of funds invests in 15-40 hedge funds, its cost of initial and ongoing due diligence will be much higher than for a portfolio of 10 hedge funds. 
Approximately 35\% of US-domiciled funds of funds have less than \$20 Million in assets under management. With an annual management fee of $1.5 \%$, a fund of funds with $\$ 20$ Million in assets generates $\$ 300,000$ in management fees annually. With the cost of performing due diligence on 10 hedge funds conservatively estimated at $\$ 500,000$ to $\$ 1$ Million, a fund of funds with $\$ 20$ Million in assets does not generate sufficient management fees to cover the cost of due diligence for the hedge funds in which it invests, let alone to cover other due diligence costs and all the other costs of operating a fund of funds.

\section{Data}

\section{A. Description of the Data}

We obtain data for this study from the Lipper TASS database for the period December1994 through December 2006. The TASS data for \$US denominated hedge fund and fund of funds returns is on an after-fee basis and includes all funds alive as of December 2006 as well as all funds that left the database at any time during that period (the graveyard funds), an average of 408 funds of funds and 1,468 other hedge funds over the sample period ${ }^{13}$. For each month, portfolios were formed on the basis of all funds for which prior month end prices and assets under management are available. The funds are ranked each month on the basis of quintiles of assets under management, and value

\footnotetext{
${ }^{13}$ Funds leave the database for many reasons. As there is no requirement to file returns data, there is little incentive for successful funds to file once they are closed to new investment. Funds can also merge or fail and be liquidated. Only recently has TASS recorded a reason for non-availability of fund data. TASS does not indicate the reason for fund failure. A recent study by Liang and Park (2007) indicates that poor fund performance is only one reason for fund failure.
} 
weighted returns are computed for each subsequent monthly holding period ${ }^{14}$. The Sharpe ratio is calculated on the basis of return in excess of the corresponding 30 day Treasury Bill return. Goetzmann et al. (2004) argue that the Sharpe ratio can be deceptive as a measure of performance when portfolio strategies lead to the kind of nonlinear payoff patterns typical for many hedge funds. To address this issue we compute alphas using the procedure suggested in Fung and Hsieh (2001). For any given month for each fund in the sample using data up to but not including the month in question, we first compute factor sensitivities by regressing fund return on the S\&P500 index return, the Fama and French SMB factor, a bond market factor and a credit spread factor, as well as three factors that capture the nonlinear payoff strategies commonly used by many hedge funds ${ }^{15}$. These factor sensitivities are applied to current factor realizations for the month in question and the result is subtracted from the fund return in that month to compute alpha ${ }^{16}$. The portfolio alphas for each month represent a value-weighted average of fund specific alphas.

\section{B. An Analysis of the Data}

Table I provides return and Sharpe ratio data for hedge funds and funds of funds for the 1995-2006 period. Not surprisingly, returns are lower for funds of funds than for hedge

\footnotetext{
${ }^{14}$ These return measures represent an upper bound on the returns on an investible portfolio due to share restrictions and lock-up provisions that are a practical limitation on the ability of investors to implement this portfolio strategy. This issue is discussed at length in Liang and Park (2007).

${ }^{15}$ These factors include a bond trend following factor, a currency trend following factor and a commodity trend following factor. These factors are described in Fung and Hsieh (2001) and the latest version of these factors are available from David Hsieh's website http://faculty.fuqua.duke.edu/ dah7/HFRFData.htm ${ }^{16}$ We also computed a standard Jensen's alpha (Jensen 1968) using the same procedure to compute alpha, using the return on the S\&P500 as the market return and 30 day Treasury Bill return as the risk-free rate used to compute the respective risk premia. It is not clear that the S\&P500 is the appropriate benchmark for hedge fund returns. Nevertheless these results (unreported) were stronger using Jensen's alpha than the reported results using the Fung and Hsieh alphas.
} 
funds over the time period. For all funds (excluding funds of funds), hedge funds delivered an annual return of $11.28 \%$ and funds of funds produced an annual return of 9.98\%. Part of the difference in returns can be explained by the additional layer of fees funds of funds charge investors. The median management fee for funds of funds is approximately $1.5 \%$ and the median incentive fee is approximately $10.0 \%$ over and above the fees charged by the constituent funds. Comparing quintiles based on prior month assets under management, funds of funds in the second, third, fourth and fifth quintiles have higher Sharpe ratios than hedge funds in the corresponding quintile.

Annual hedge fund returns are highest for small hedge funds and lowest for large hedge funds. Hedge fund returns after fees are highest for hedge funds in the second quintile (14.63\%) and lowest for hedge funds in the fifth quintile (11.03\%). Interestingly, the opposite holds true for funds of funds. Fund of funds returns after all fees are paid are highest for large funds of funds and lowest for small funds of funds. Fund of funds returns are highest for funds of funds in the fifth quintile (10.14\%) and lowest for funds of funds in the first quintile (7.45\%). The difference in performance between funds of funds in the fifth quintile and funds of funds in the first quintile (2.69\%) is statistically and economically significant. Sharpe ratios are also more than twice as large for large funds of funds than for small funds of funds.

One reasonable explanation for these findings might be that it is well understood that individual hedge funds may take risk positions that are considerably different from those of funds of funds. Large funds of funds are necessarily highly diversified across strategies 
and styles, and the differences in return we see in Table 1 might be attributed to differences in beta risk exposure. To address this concern, we compute alpha using a risk equivalent benchmark based on seven factors suggested by Fung and Hseih (2001). Alphas of large funds of funds are significantly higher than those of small funds of funds (with a $t$-value of 2.63), evidence of significant economies of scale, while the alphas of hedge funds excluding funds of funds show evidence of diseconomies of scale (with a $t$ value of -2.17$)^{17}$. This exercise further supports the proposition that there are diseconomies of scale in hedge funds, but significant economies of scale in funds of funds.

As evidenced by the data in Table I, the competitive advantage of large funds of funds is significant. Funds of funds large enough to absorb the high cost of due diligence have in principal a significant competitive advantage over smaller funds of funds. But do they exploit this advantage? In Table 2 we examine the pattern of use of service providers to the industry. As a general rule, the larger the fund, the more likely it is to use well known service providers. An index of what constitutes a well known service provider is the extent to which that service provider is used by more than one other fund. This difference is significant for most classes of service providers, and is particularly large when we consider auditor services. Only 23.6 percent of small funds of funds use well known auditors, whereas 42.3 percent of large funds of funds use well known auditors. ${ }^{18}$ This

\footnotetext{
${ }^{17}$ The results were not sensitive to the use of Fung and Hsieh alphas. The results were stronger using alphas measured relative to the S\&P500, with t-values of 2.44 for funds of funds and -2.89 for hedge funds excluding funds of funds.

${ }^{18}$ This result is also found by Liang (2003) who found that the larger the fund, the more likely it is to use a big five (4) auditing firm whereas small funds cannot afford to do so. Table 2 shows that this result also applies to other external service providers.
} 
does not prove of course that small funds of funds do not do the appropriate due diligence. Rather it supports the notion that they lack the necessary funding to compete effectively with their larger brethren. The economies of scale that we document in funds of funds are quite substantial and support the proposition that due diligence is an important source of alpha in hedge fund investment.

\section{Conclusions}

The principal finding of our paper is the somewhat surprising conclusion that operational due diligence is an important source of alpha in hedge fund investment. As the data show, funds of funds large enough to absorb the high cost of due diligence have a significant competitive advantage over smaller funds of funds. Funds of funds in the fifth quintile, based on prior month assets under management, outperformed funds of funds in the first quintile by 269 basis points, a statistically and economically significant amount. Funds of funds generate dramatic economies of scale. The due diligence program of a well-managed fund of funds should be designed to take advantage of the role due diligence can play in generating alpha. The potential return on an appropriate investment in due diligence is compelling.

The findings of this paper have several important implications for managers of funds of funds and other investors who invest in portfolios of hedge funds, like foundations and endowments. First, while performing due diligence is a necessary part of the role of a fiduciary, the greater value of due diligence lies in the fact that it can play a very active role in generating alpha. Thus, fund of funds managers should budget and staff for due 
diligence accordingly. For example, hiring attorneys can add positive net present value. Second, the value of due diligence lies more in avoiding hedge funds that underperform or go out of business than it does in selecting top performing hedge funds. Thus, the due diligence process should place significant emphasis on operational risk and operational due diligence. Third, and perhaps most interesting, due diligence can be a profit center. Alpha is very difficult to generate. This research demonstrates a way to generate alpha that is non-obvious, novel and currently relatively under-pursued. 


\section{$\underline{\text { References }}$}

Amin, Gaurav S. and Kat, Harry M., "Welcome to the Dark Side: Hedge Fund Attrition and Survivorship Bias Over the Period 1994-2001,” Journal of Alternative Investments (Summer 2003), Vol. 6, Issue 1, pp. 57-73.

Ang, Andrew, Rhodes-Kropf, Matthew and Zhao, Rui, "Do Funds-of-Funds Deserve Their Fees-on-Fees?" (November 20, 2005). AFA 2007 Chicago Meetings Paper Available at SSRN: http://ssrn.com/abstract=687274

Anson, Mark J.P., Handbook of Alternative Investments (John Wiley \& Sons, Inc. 2006).

Asness, Clifford, Krail, Robert and Liew, John, “Do Hedge Funds Hedge?” Journal of Portfolio Management (Fall 2001), pp. 6-19.

Brown, Stephen J., Goetzmann, William N. and Ibbotson, Roger G., “Offshore Hedge Funds: Survival and Performance, 1989-1995,” Journal of Business (January 1999), Vol. 72, Issue 1, pp. 91-117.

Brown, Stephen J., Goetzmann, William N. and Park, James, "Careers and Survival: Competition and Risk in the Hedge Fund and CTA Industry," Journal of Finance (October 2001), Vol. 61, No. 5, pp. 1869-1886.

Brown, Stephen J., Goetzmann, William N., Liang, Bing, "Fees on fees in funds of funds,” Journal of Investment Management 3, 2004 pp.39-56.

Brown, Stephen J., Goetzmann, William N., Liang, Bing and Schwarz, Christopher, "Optimal Disclosure and Operational Risk: Evidence from Hedge Fund Registration," Journal of Finance 2008 (forthcoming). Available at SSRN:

http://ssrn.com/abstract=918461.

Ding, Bill, Getmansky, Mila, Liang, Bing, and Wermers, Russ R. "Investor Flows and Share Restrictions in the Hedge Fund Industry" (May 29, 2007). Available at SSRN: http://ssrn.com/abstract $=891732$

Edwards, Franklin R. and Caglayan, Mustafa Onur, "Hedge Fund Performance and Manager Skill,” Journal of Futures Markets (2001), Vol. 21, No. 11, pp. 1003-1028.

Feffer, Stuart and Kundro, Christopher, "Understanding and Mitigating Operational Risk in Hedge Fund Investments: A Capco White Paper” (March 2003). Available at: www.capco.com/WorkArea/showcontent.aspx?id=2444.

Fung, William and Hsieh, David A., The Risk in Hedge Fund Strategies: Theory and Evidence from Trend Followers," Review of Financial Studies, 14 (2001), 313-341. 
Fung, William and Hsieh, David A., "Hedge Fund Benchmarks: A Risk Based Approach,” Financial Analysts Journal (September/October 2004), Vol. 60, No. 5, pp. 65-80.

Goetzmann, William N., Ingersoll Jr., Jonathan E., Spiegel, Matthew I. and Welch, Ivo, "Portfolio Performance Manipulation and Manipulation-Proof Performance Measures" (November 2004). Available at SSRN: http://ssrn.com/abstract=302815

Ibbotson, Roger G. and Chen, Peng, “The A, B, Cs of Hedge Funds: Alphas, Betas, and Costs” (September 2006). Yale ICF Working Paper No. 06-10. Available at SSRN: http://ssrn.com/abstract=733264.

Jensen, Michael, “The performance of mutual funds in the period 1945-1964”. Journal of Finance (1968), Vol. 23, Issue 2, 389-416

Kouwenberg, Roy, "Do Hedge Funds Add Value to a Passive Portfolio? Correcting for Non-Normal Returns and Disappearing Funds,” Journal of Asset Management (March 2003), Vol. 3, Issue 4, pp. 361-382.

Lhabitant, Francois-Serge and Learned, Michelle, "Hedge Fund Diversification: How Much Is Enough?” Journal of Alternative Investments (Winter 2002), Vol. 5, Issue 3, pp. 23-49.

Liang, Bing, "Hedge Funds: the Living and the Dead," Journal of Financial and Quantitative Analysis (September 2000), Vol. 35, No. 3, pp. 309-326.

Liang, Bing, “Hedge Fund Performance: 1990-1999,” Financial Analysts Journal (January/February 2001), Vol. 57, No. 1, pp. 11-18.

Liang, Bing, "Hedge Fund Returns: Auditing and Accuracy," Journal of Portfolio Management 29, 111-122, Spring 2003.

Liang, Bing, and Hyuna Park, "Predicting Hedge Fund Failure: A Comparison of Risk Measures" (October 2007). Available at SSRN: http://ssrn.com/abstract=983209 
Table I: Economies of Scale

\begin{tabular}{|c|c|c|c|c|c|c|c|}
\hline & \multicolumn{5}{|c|}{ Prior month assets under management } & \multirow[b]{2}{*}{$\begin{array}{c}t \text {-value } \\
\text { (large - small) }\end{array}$} \\
\hline & & $1^{\text {st }}$ & $2^{\text {nd }}{ }^{\text {quintile }}$ & $\begin{array}{c}3^{\text {rd }} \\
\text { quintile }\end{array}$ & $\begin{array}{c}4^{\text {th }} \\
\text { quintile }\end{array}$ & $\begin{array}{c}5^{\text {th }} \\
\text { quintile }\end{array}$ & \\
\hline \multirow{4}{*}{$\begin{array}{c}\text { All hedge } \\
\text { Funds } \\
\text { (excl. } \\
\text { FoF) }\end{array}$} & $\begin{array}{c}\text { Value } \\
\text { weighted } \\
\text { returns }\end{array}$ & $14.47 \%$ & $14.63 \%$ & $12.87 \%$ & $11.50 \%$ & $11.03 \%$ & $-(2.01)$ \\
\hline & Fung-Hsieh & $9.94 \%$ & $10.47 \%$ & $9.01 \%$ & $7.50 \%$ & $7.47 \%$ & $-(2.17)$ \\
\hline & & (9.73) & (11.31) & (10.23) & (8.66) & (5.7) & \\
\hline & Sharpe ratio & 0.107 & 0.133 & 0.128 & 0.122 & 0.117 & \\
\hline \multirow{4}{*}{$\begin{array}{l}\text { Funds of } \\
\text { Funds }\end{array}$} & $\begin{array}{c}\text { Value } \\
\text { weighted } \\
\text { returns }\end{array}$ & $7.45 \%$ & $9.25 \%$ & $8.90 \%$ & $9.54 \%$ & $10.14 \%$ & $(2.78)$ \\
\hline & Fung-Hsieh & $4.72 \%$ & $6.46 \%$ & $6.61 \%$ & $6.90 \%$ & $6.77 \%$ & $(2.63)$ \\
\hline & alpha & $(4.73)$ & $(6.53)$ & $(6.9)$ & $(6.98)$ & $(5.96)$ & \\
\hline & Sharpe ratio & 0.074 & 0.134 & 0.152 & 0.180 & 0.213 & \\
\hline
\end{tabular}

All TASS \$US Funds 1995-2006. Value weighted annual returns, value weighted annualized alpha in bold and Sharpe ratio in italics. For each month, portfolios were formed on the basis of all \$US denominated funds for which prior month end prices and assets under management are available on the Lipper TASS database. The funds were ranked by quintiles of assets under management for all hedge funds excluding funds of funds, and for funds of funds. Value weighted returns net of fees were computed for each subsequent monthly holding period. The table also reports annual returns for all \$US funds (excluding funds of funds) and funds of funds. For each fund, the annualized alpha is twelve times the monthly value weighted alpha computed using seven hedge fund factors described in Fung and Hseih (2001), and downloaded from http://faculty.fuqua.duke.edu/ dah7/HFRFData.htm. The Sharpe ratio measures the average monthly return in excess of the corresponding 30 day Treasury Bill return in units of the standard deviation of monthly returns, and the $t$-value is the $t$-statistic testing the significance of the $5^{\text {th }}$ quintile portfolio return in excess of the $1^{\text {st }}$ quintile portfolio return and alpha respectively. All $t$-values are in parentheses. 
Table 2: Fraction of funds using well known service providers

\begin{tabular}{|c|c|c|c|c|c|c|c|c|}
\hline & & \multicolumn{5}{|c|}{ Prior month assets under management } & \multirow[b]{2}{*}{$\begin{array}{c}\text { All } \\
\text { Funds }\end{array}$} & \multirow[b]{2}{*}{$\begin{array}{c}t \text {-value } \\
\text { (large - small) }\end{array}$} \\
\hline $\begin{array}{l}\text { Service } \\
\text { Provider }\end{array}$ & & $1^{\text {st }}$ & $2^{\text {nd }}$ & $3^{\text {quintile }}$ & $4^{\text {th }}$ & $5^{\text {th }}$ & & \\
\hline $\begin{array}{l}\text { Legal } \\
\text { Counsel }\end{array}$ & $\begin{array}{l}\text { All funds (excl FoF) } \\
\text { Funds of funds }\end{array}$ & $\begin{array}{l}13.3 \% \\
11.7 \%\end{array}$ & $\begin{array}{l}12.7 \% \\
12.0 \%\end{array}$ & $\begin{array}{l}14.7 \% \\
11.9 \%\end{array}$ & $\begin{array}{l}11.4 \% \\
14.0 \%\end{array}$ & $\begin{array}{l}15.0 \% \\
14.0 \%\end{array}$ & $\begin{array}{l}13.4 \% \\
12.7 \%\end{array}$ & $\begin{array}{l}0.38 \\
1.03\end{array}$ \\
\hline $\begin{array}{l}\text { Custodian } \\
\text { Services }\end{array}$ & $\begin{array}{l}\text { All funds (excl FoF) } \\
\text { Funds of funds }\end{array}$ & $\begin{array}{l}10.7 \% \\
15.2 \%\end{array}$ & $\begin{array}{l}18.2 \% \\
20.3 \%\end{array}$ & $\begin{array}{l}17.4 \% \\
19.4 \%\end{array}$ & $\begin{array}{l}21.5 \% \\
24.2 \%\end{array}$ & $\begin{array}{l}24.8 \% \\
28.6 \%\end{array}$ & $\begin{array}{l}19.1 \% \\
21.4 \%\end{array}$ & $\begin{array}{l}2.77 \\
4.89\end{array}$ \\
\hline $\begin{array}{l}\text { Prime } \\
\text { Broker }\end{array}$ & $\begin{array}{l}\text { All funds (excl FoF) } \\
\text { Funds of funds }\end{array}$ & $\begin{array}{l}13.0 \% \\
18.3 \%\end{array}$ & $\begin{array}{l}16.9 \% \\
21.0 \%\end{array}$ & $\begin{array}{l}19.7 \% \\
17.8 \%\end{array}$ & $\begin{array}{l}22.4 \% \\
25.8 \%\end{array}$ & $\begin{array}{l}20.8 \% \\
28.9 \%\end{array}$ & $\begin{array}{l}19.0 \% \\
22.3 \%\end{array}$ & $\begin{array}{l}1.58 \\
3.80\end{array}$ \\
\hline $\begin{array}{l}\text { Auditor } \\
\text { Services }\end{array}$ & $\begin{array}{l}\text { All funds (excl FoF) } \\
\text { Funds of funds }\end{array}$ & $\begin{array}{l}19.2 \% \\
23.6 \%\end{array}$ & $\begin{array}{l}26.7 \% \\
27.4 \%\end{array}$ & $\begin{array}{l}25.8 \% \\
26.1 \%\end{array}$ & $\begin{array}{l}26.9 \% \\
35.8 \%\end{array}$ & $\begin{array}{l}33.2 \% \\
42.3 \%\end{array}$ & $\begin{array}{l}26.8 \% \\
30.9 \%\end{array}$ & $\begin{array}{l}2.42 \\
6.01\end{array}$ \\
\hline $\begin{array}{l}\text { Administrator } \\
\text { Services }\end{array}$ & $\begin{array}{l}\text { All funds (excl FoF) } \\
\text { Funds of funds }\end{array}$ & $\begin{array}{l}10.4 \% \\
15.0 \%\end{array}$ & $\begin{array}{l}17.7 \% \\
16.8 \%\end{array}$ & $\begin{array}{l}17.6 \% \\
16.2 \%\end{array}$ & $\begin{array}{l}17.1 \% \\
20.8 \%\end{array}$ & $16.6 \%$ & $\begin{array}{l}16.3 \% \\
18.6 \%\end{array}$ & 1.38 \\
\hline
\end{tabular}

All TASS \$US Funds 2006. For each month in 2006 all \$US denominated funds for which prior month end prices and assets under management were available in the Lipper TASS universe were ranked in quintiles of assets under management for both Funds of funds and all hedge funds (excluding funds of funds). For each asset class the fraction of funds using service providers used by more than one other fund was tabulated. The $t$ value gives the test of significance of the difference in proportions between the smallest quintile and the largest quintile of funds. 